\title{
Pelatihan Dasar Kepemimpinan: Peran dan Kewajiban Mahasiswa di Universitas Bumigora
}

\author{
Erwin Suhendra ${ }^{1}$, Lela Rahmawati ${ }^{2}$, Baiq Candra Herawati ${ }^{3}$, Gilang Primajati ${ }^{4}$, Wahyu \\ Kamil Syarifaturrahman ${ }^{5}$ \\ erwindebater@gmail.com¹, lelarahmawati13@gmail.com², \\ candrah@universitasbumigora.ac.id ${ }^{3}$, gilangprimajati@universitasbumigora.ac.id ${ }^{4}$, \\ wahyu.kamil@universitasbumigora.ac.id ${ }^{5}$.
}

\section{1,2,3,4,5 Universitas Bumigora}

\section{Article History:}

Received: 18-12-2021

Revised: 19-01-2022

Accepted: 21-01-2022

Keywords: Management, Leadership training, Conflict resolution

\begin{abstract}
This public service is aim to give knowledge and understanding to students in Universitas Bumigora. This service activity is a student's management leadership training for basic level. Students' needs to understand that they have important role and responsibilities in societies and in the college; students are also needs to learn how to manage their selves; to identify leadership identities and to handle conflict. The method used in this public service is three stages; pre-test, workshop and post-test. The participants are students in Universitas Bumigora especially the freshman year. The result obtained is to open horizons of thought that students' part in the future is important not only to themselves but also to the region, further to our country. Therefore, given knowledge in this student's management leadership training for basic level expand students understanding in the college and in the community.
\end{abstract}

\section{Pendahuluan}

Mahasiswa sebagai peserta didik tingkat akhir di jenjang pendidikan formal memliki peran yang penting dalam kemajuan sebuah bangsa dan negara. Oleh karena itu, mahasiswa memiliki tuntutan yang banyak, baik itu dari segi sosial maupun dari segi akademis. Dari segi sosial mahasiswa memiliki keterikatan kepada keluarganya, kerabatnya serta lingkungan masyarakat tempat ia tinggal yang tentunya setelah mahasiswa selesai menempuh jenjang Pendidikan tinggi, mereka akan kembali ke masyarakat untuk memberikan kontribusi pengembangan SDM kepada daerah tersebut.

Mahasiswa di Universitas Bumigora mengalami penurunan kegiatan kegiatan kemahasiswaan selama pandemi COVID-19. Selain pembatasan ruang diskusi secara tatap muka, mahasiswa juga memiliki beberapa kendala jika mengadakan pertemuan secara daring, diantaranya: Kuota internet, koneksi, dsb. Praktis, mahasiswa hanya mendapatkan pelajaran dari kelas saja dan kondisi ini kami rasa perlu diperhatikan agar mahasiswa tetap mendapatkan hak dan kewajibannya. Untuk itu, bekerjasama dengan Badan Eksekutif Mahasiswa Universitas Bumigora, kami mengadakan pelatihan dasar kepemimpinan.

Tujuan dari Pengabdian kepada Masyarakat ini adalah untuk memberikan 
pemahaman mendasar kepada mahasiswa tentang arti pentingnya mahasiswa di masa depan. Untuk itu dosen Universitas Bumigora bermitra dengan Badan Eksekutif Mahasiswa (BEM) Universitas Bumigora untuk menyelenggarakan kegiatan pelatihan keterampilan manajemen mahasiswa tingkat dasar. Dalam kegiatan ini materi yang diajarkan kepada mahasiswa berupa; analisis peran dan tugas mahasiswa di masyarakat dan kampus, regulasi diri, kepemimpinan dan resolusi konflik.

Untuk mencapai tujuan tersebut dosen di Universitas Bumigora dan Badan Eksekutif Mahasiswa melaksanakan kegiatan pelatihan keterampilan manajemen mahasiswa tingkat dasar dalam bentuk seminar dan workshop serta games, sehingga tidak hanya memberikan pemahaman secara kognitif juga kegiatan ini diharapkan mampu membuka wawasan mahasiswa.

\section{Metode}

Kegiatan pengabdian ini memiliki tujuan untuk memberikan pemahaman serta wawasan kepada mahasiswa dalam menjalankan peran dan kewajiban mereka sebagai mahasiswa. Kegiatan ini dilaksanakan dalam tiga tahap, diantaranya; pre-test, workshop dan post-test. Adapun rincian kegiatan yang dilakukan pada tiap tahap tersebut sebagai berikut:

\section{a. Pre-test}

Tahap ini dilaksanakan sebelum pelaksanaan workshop. Pelaksanaan pre-test dimaksudkan untuk mengetahui pemahaman serta peserta pelatihan keterampilan manajemen mahasiswa tingkat dasar sebelum mahasiswa mengikuti kegiatan workshop yang telah disiapkan oleh pemateri.

b. Workshop

Tahap ini dilakukan untuk memberikan wawasan pengetahuan pada mahasiswa tentang pentingnya peran dan kewajiban mahasiswa dalam masyarakat dan kampus. Selain itu materi yang diberikan juga mencakup tentang identitas kepemimpinan, regulasi diri serta resolusi konflik,

c. Post-test

Tahap ini dilaksanakan setelah seluruh peserta pelatihan ketermapilan manajemen mahasiswa tingkat dasar menyerap informasi dan wawasan yang telah disampaiakan oleh pemateri. Post-test ini juga dimaksudkan sebagai evaluasi atas pemahaman mahasiswa tentang materi yang telah diberikan.

Metode pengabdian: 


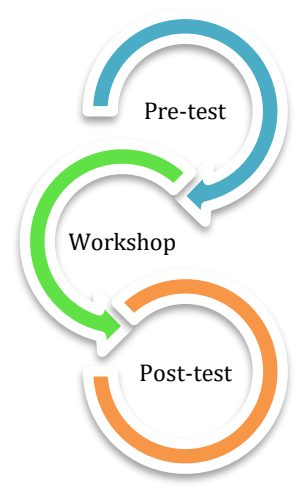

Gambar 1. Metode pengabdian

\section{Pembahasan}

Sebelum pelaksanaan program pelatihan/workshop mahasiswa Universitas Bumigora diberikan pre-test untuk mengukur pemahaman akan peran dan kewajiban mereka sebagai mahasiswa. Dari hasil kuesioner yang diberikan secara umum $68 \%$ peserta pelatihan memahami peran mahasiswa sebagai pionir intelektual mayarakat yang bertugas untuk mengatur dan mengubah paradigma sebagai solusi terhadap problem yang ada. Secara individu, peserta juga memiliki kemampuan dalam mengelola waktu yang cukup baik serta pemahaman mereka akan organisasi cukup baik; bagaimana komunikasi antara pimpinan ormawa dengang anggotanya, bagaimana sebuah konflik harus diselesaikan, dsb.

Dalam kegiatan pengabdian masyarakat ini dilakukan program pelatihan/workshop pada mahasiswa di Universitas Bumigora. Wawasan keterampilan manajemen tingkat dasar yang diberikan kepada mahasiswa tentang peran dan kewajiban mahasiswa di masyarakat dan di kampus, regulasi diri, identitas kepemimpinan serta resolusi konflik.

Peran mahasiswa dalam masyarakat tebagi menjadi tiga: agent of change; social control dan iron stock (Susan, 2016). Sebagai agent of change mahasiswa seyogyanya berupaya dalam memberikan perubahan dan perbaikan di bidang sosial masyarak dimulai dari lingkup paling kecil, yakni menjaga kebersihan lingkungan dari sampah, baik itu dari lingkungan keluarga hingga lingkungan tempat mereka tinggal. Sebagai social control, mahasiswa perlu memiliki pemikiran kritis dan Analisa yang kuat dalam menelaah kebijakankebijakan organisasi (pemerintah dan kampus) hal ini ditegaskan oleh (Santoso, 2015) mahasiswa perlu mendalami dan menerapkan ilmu yang didapat selama kuliah dan ilmu tersebut ia gunakan untuk mengkritisi hal-hal yang terjadi di masyrakat kampus dan masyarakat luas. Tidak cukup sampai disitu, mahasiswa juga harus menjadi teladan (Iron Stock) hal ini didasari oleh mahasiswa yang memiliki intelektualitas pengetahuan serta keterampilan yang lebih baik dari masyarakat kebanyakan yang seharusnya dapat dioptimalkan dalam bentuk pribadi yang kuat secara pemikiran dan dapat menjadi contoh dalam pengambilan keputusan terhadap persoalan-persoalan yang ada di masyarakat. 
Ketiga peran mahasiswa tersebut tidak dapat terlaksana secara maksimal jika mahasiswa juga melaksanakan kewajiban utamanya di kampus sebagai peserta didik. Peran sebagai mahasiswa tersebut dilaksanakan dengan pengembangan kompetensi di bidang akademik serta meningkatkan kemampuan dalam hal literasi yang keduanya akan memudahkan mahasiswa dalam menyelesaikan studi dikampus.

Kompleksitas masalah dalam menjalani peran dan kewajiban mahasiswa tentu membutuhkan manajerial diri dalam menghadapi berbagai persoalan tersebut. (Santrock, 2007) menyebutkan adanya regulasi diri dalam belajar akan membuat individu mengatur tujuan, mengevaluasinya dan membuat adaptasi yang diperlukan sehingga menunjang dalam prestasi. Hasil penelitian lainnya juga menunjukkan bahwa regulasi diri dalam belajar mempunyai peranan yang besar dalam pencapaian prestasi akademik seseorang (Zimmerman, 1990; Montalvo \& Gonzalez, 2004; Cheng, 2011).

Leadership identity adalah proses yang dialami oleh seseorang untuk menjadi pemimpin melalui 6 tahap, yang dimulai dengan kesadaran diri untuk mengidentifikasi potensi yang ada di dalam diri seorang individu. Menurut Komives. et al., (2005) tahapan tersebut adalah; 1) awareness, yaitu kesadaran seseorang terhadap figure pemimpin yang ada di lingkungannya serta kemampuan seseorang tersebut dalam membedakan pemimpin, 2) Exploration, yaitu pertisipasi seseorang dalam sebuah organisasi, 3) Leader Identified, yaitu kemampuan seseorang dalam membedakan peran dan tanggungjawab sebagai seorang pemimpin, 4) Leadership Differentiated, kemampuan seseorang dalam membedakan peran dan tanggungjawab pemimpin berdasarkan tugas kepemimpinannya, 5) Generativity, individu mengembangkan peran kepemimpinan kepada para anggotanya, 6) Integration, yaitu kemampuan seseorang dalam menerapkan aspek kepemimpinan dalam kehidupannya sehari-hari.

Konflik interpersonal bisa berasal dari ketidaksesuaian persepsi terhadap tujuan hingga dihambatnya pencapaian tujuan oleh pihak lain. Johnson \& Johnson (1997) menyatakan, jika tindakan seseorang dalam memenuhi kebutuhan ataupun tujuannya telah dipandang menghalangi tindakan orang lain sehingga menjadi tidak efektif, maka terjadilah konflik. Terdapat tiga hal penting yang menandai kelahiran konflik, yakni (1) adanya hubungan interelasional, (2) adanya perbedaan pandangan dan tujuan yang dipersepsikan sangat penting, dan (3) adanya penghalangan pencapaian tujuan (Deutsch \& Coleman, 2000; Johnson \& Johnson, 1997). Dengan menerapkan strategi collaborative dalam resolusi konflik menandakan bahwa mahasiswa mampu berbagi informasi secara terbuka, menganalisis permasalah bersama, saling memahami antar sesame dengan keterbukaan perasaan dan pikiran, serta kompak dalam hal-hal yang akan menguntungkan Bersama (Song et al., 2006; Stevahn \& King, 2005).

Setelah pemaparan materi dilakukan, peserta diberikan kesempatan untuk https://journal.universitasbumigora.ac.id/index.php/ADMA 
melaksanakan forum Group Discussion untuk dapat menyerap secara komprehensif materi pelatihan. Setelah itu, peserta pelatihan diberikan post-test kuesioner. Dari hasil kuesioner mahasiswa dapat dikatakan memiliki pemahaman yang sangat baik akan peran dan kewajiban mereka sebagai mahasiswa di Universitas Bumigora. Peserta dapat memahami kewajiban dasar mereka yaitu belajar dan peran mereka baik itu di keluarga dan masyarakat memiliki dampak yang sedikit tidak akan berpengaruh dalam membentuk pola masyarakat seperti apa yang akan terbangun di daerahnya masing-masing.
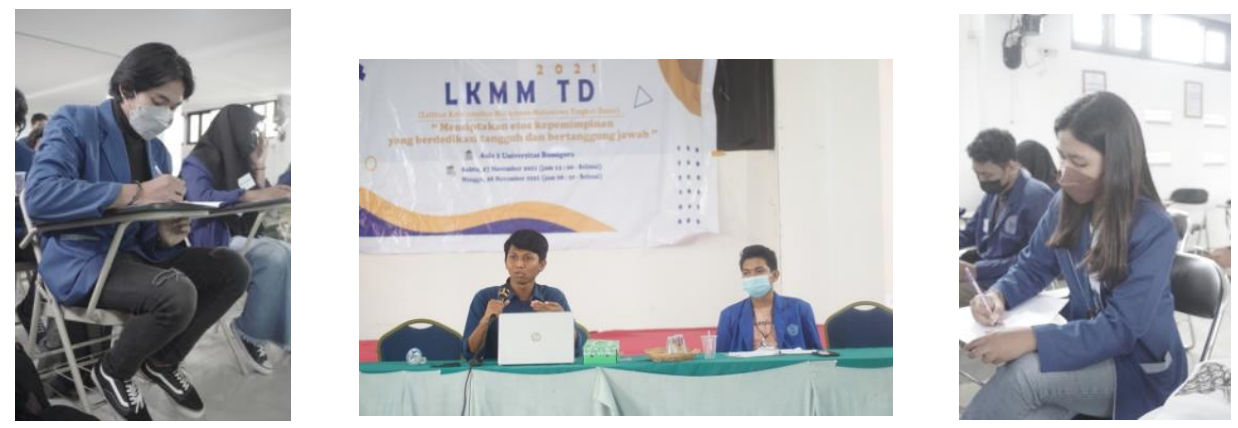

Gambar 2. Foto Dokumentasi Kegiatan

\section{Kesimpulan}

Para peserta pengabdian sudah lebih dapat mememahami peran dan kewajiban sebagai mahasiswa. Para peserta pengabdian juga sudah dapat membagi prioritas diri dalam menjalankan peran mereka sebagai mahasiswa dan sebagai bagian dari masyarakat

\section{Ucapan Terimakasih}

Ketua pelaksana pengabdian menyampaikan ucapan terima kasih dan apresiasi yang tinggi kepada para pelaksana pengabdian dan juga dosen yang telah melakukan pengabdian kepada masyarakat, dalam hal ini adalah mahasiswa Universitas Bumigora. Pelatihan Kepemimpinan Manajemen Mahasiswa Tingkat Dasar memiliki peran yang penting dalam pengembangan kompetensi mahasiswa. Ucapan terimakasih juga ditujukkan kepada para mitra yaitu Badan Eksekutif Mahasiswa Universitas Bumigora yang membantu penyelenggaraan kegiatan pelatihan ini. Dengan telah berhasil dilakukannya pelatihan kepemimpinan ini mahasiswa diharapkan mampu menjalankan perannya baik di kampus maupun di masyarakat. 


\section{Daftar Pustaka}

Cheng, E. C. (2011). The role of self regulated learning in enhancing learning performance. The International Journal of Research and Review, 6(1), 1-16.

Deutsch, M., \& Coleman, P. (2000). The Handbook of Conflict Resolution. Josey Bass.

Johnson, D. W., \& Johnson, F. P. (1997). Effects on Hight School Students of Conflict Resolution Training Integrated into English Literature. The Journal of Social Psychology, 137(3), 302-315.

Komives., Owen., Longerbeam., \& Osteen. (2005). Developing a leadership identity: Agrounded theory. journal of college student development. 46(1), 593-611.

Montalvo, F. T., \& Gonzalez, M. C. (2004). Self regulated learning: current and future directions. Electronic Journal of Research in Educational Psychology, 2(1), 1-34.

Santoso, U. (2015). Apa Tugas dan Peran Mahasiswa? http://sivitasakademika.wordpress.com/2015/04/19/apa-tugas-dan-peran-mahasiswa/

Santrock, J. W. (2007). Educational psychology. In Educational Psychology. McGrawHill Companies, Inc.

Song, M., Barbara, D., \& Jeffrey, R. T. (2006). Conflict Management and Innovation Performance: An Integrated Contingency Perspective. Journal of The Academy of Marketing Science, 34(3), 341356.

Stevahn, L., \& King, J. A. (2005). Managing Conflict Constructively in Program Evaluation. Evaluation, $11(4), 415-427$.

Susan, I. I. S. dan H. dan S. (2016). . Ilma Surya Istiqomaharani Sandra Susan Habibah. Mewujudkan Peran Mahasiswa Sebagai "AGEN OF CHANGE, SOSIAL CONTROL, DAN IRON STOCK," 1(2), 2.

Zimmerman, B. J. (1990). Self regulated learning and academic achievment: an overview. Educational Pstchologist, 25(1), 3-17. 